\title{
Duchenne Muscular Dystrophy in a Female Child with Turner syndrome: A Case report
}

\author{
Nahrel $\mathbf{R}^{1}$, Kosam $\mathbf{A}^{2}$ \\ ${ }^{1}$ Dr Rakesh Nahrel, Associate Professor, ${ }^{2}$ Dr Ajay Kosam, Assistant Professor, Department of Pediatrics, Chhattisgarh \\ Institute of Medical Sciences, Bilaspur, Chhattisgarh, India.
}

Address for Correspondence: Dr Ajay Kosam, Email: kosamajay@gmail.com

\begin{abstract}
Duchenne Muscular Dystrophy (DMD) is a severe, progressive, $\mathrm{X}$ linked muscular wasting disorder that ordinarily has full clinical expression only in males. Females are affected in rare instances. We report a case of Duchenne Muscular Dystrophy in a female child with Turner's syndrome.
\end{abstract}

Key words: Duchenne Muscular Dystrophy, Dystrophin, Turner’s syndrome.

\section{Introduction}

Duchenne Muscular Dystrophy is the most common muscular dystrophy affecting 1 in 3500 boys born worldwide [1,2]. DMD is caused by mutations in the gene encoding Dystrophin protein [3]. This disorder almost exclusively affects males because of the $\mathrm{X}$ - linked inheritance pattern. Female dystrophinopathy rarely occurs due to three mechanisms i.e. Turner syndrome (XO), translocations between $\mathrm{X}$ and autosomal chromosomes and skewed $\mathrm{X}$ chromosome inactivation [4].

\section{Case Report}

A 9 year old female child was brought with history of progressively increasing weakness of lower limbs since the age of 2 years. She was the youngest of 3siblings in her family. The elder sister was 12 years and elder brother 10 years old. The age of father was 42 years and mother 38 years old. The parents were healthy and unrelated. The elder sister and brother were also healthy There was no family history of similar illness in paternal or maternal side.

She had abnormal gait initially followed by difficulty in rising up from sitting position and climbing stairs. The weakness had increased since last 5 months. On examination the child had short stature (Height $118 \mathrm{~cm},<-2 \mathrm{SD}$ ), US: LS 1: 1, short neck, low posterior hair line, broad shield like chest with widely spaced and hypoplastic nipples and high arched palate suggestive of Turner syndrome. (fig 1) There was pseudo hypertrophy of calf muscle, hyperlordosis with wide based waddling gait, positive Gower's sign and diminished knee jerk suggestive of DMD. (fig 2) She had developmental delay with mental subnormality. Examination of respiratory, cardiovascular and gastrointestinal system was normal.

Investigations showed markedly elevated serum creatinine kinase of $5572 \mathrm{U} / \mathrm{L}$. Muscle biopsy of left quadriceps muscle revealed muscle fibre splitting, degeneration, necrosis and hypertrophy suggestive of muscular dystrophy. Ultrasound of abdomen demonstrated hypoplastic uterus and streak ovaries. Buccal smear preparation showed absent Barr body or negative sex chromatin suggestive of Turner's syndrome. X ray chest, ECG and Echocardiography were normal. Serum creatinine kinase of mother and elder sister was normal.

The diagnosis of DMD was made on the basis of clinical profile, markedly elevated serum CK and muscle biopsy report whereas Turner's syndrome was diagnosed on the basis of clinical profile and buccal smear preparation showing negative sex chromatin. 


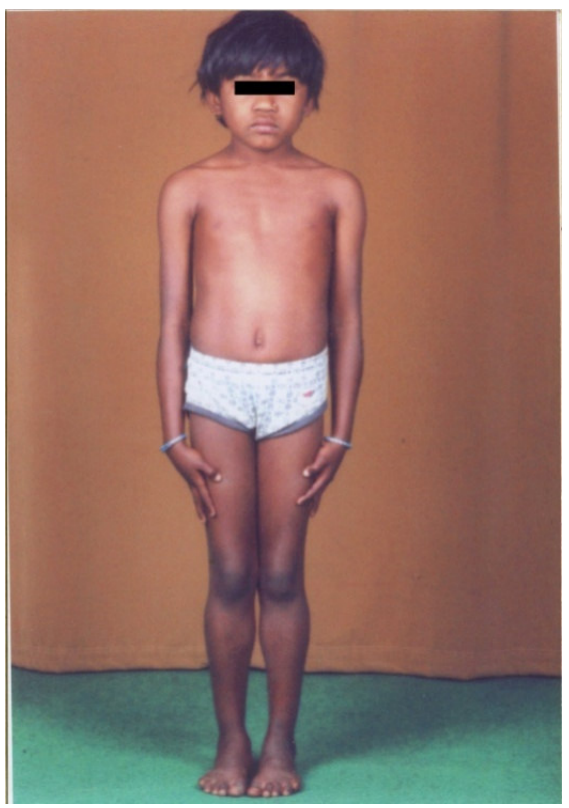

Fig 1 - Turner's phenotype.

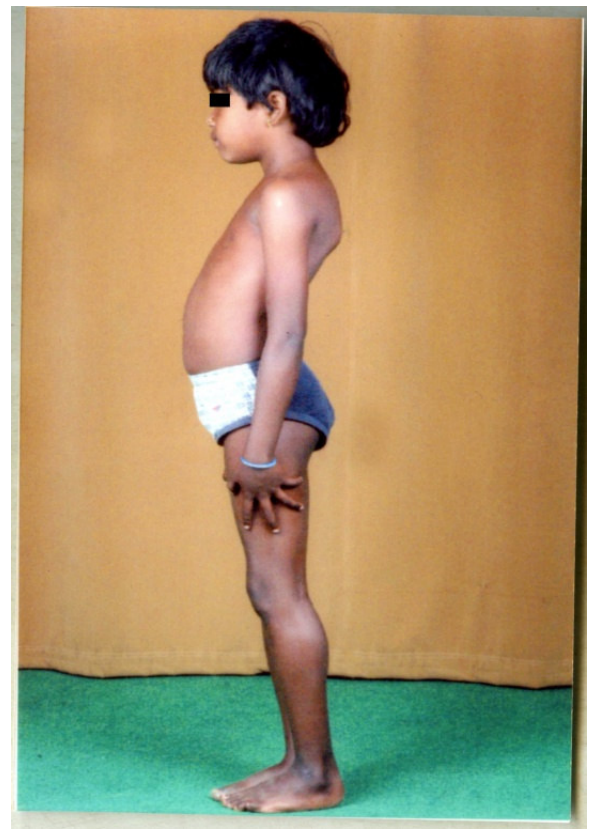

Fig 2 - Turner's phenotype with pseudo hypertrophy of calf muscles.

\section{Discussion}

The muscular dystrophies are a group of inherited and progressive muscle diseases. Duchenne muscular dystrophy (DMD) is the most common X-linked disorder in man, with an incidence of about 1 in 3500 live male births and a prevalence rate of about 3 per 100,000 population [2]. This disorder is caused by a mutation in the dystrophin gene, located in humans on the $\mathrm{X}$ chromosomes (Xp21). The dystrophin gene codes for the protein dystrophin. Dystrophin, a 400kb protein is localized at the sarcoplasmic membrane of normal skeletal muscle and comprises approximately $0.01-0.001 \%$ of total fraction of muscle protein [3]. Dystrophin is also normally expressed in cardiac muscles, visceral and smooth muscles and brain. Lack of 
Dystrophin causes breakdown of muscle fibers and loss of muscle power. Dystrophin can easily be detected in a small muscle biopsy specimen using anti dystrophin antibodies [5].

Duchenne established the diagnostic criteria for DMD. These criteria include (1) weakness with onset in the legs; (2) hyperlordosis with wide-based gait; (3) hypertrophy of weak muscles; (4) progressive course over time; (5) reduced muscle contractility on electrical stimulation in advanced stages of the disease; and (6) absence of bladder or bowel dysfunction, sensory disturbance, or febrile illness.

The case reported here is that of a girl with Turner's syndrome and Duchenne type muscular dystrophy fulfilling the diagnostic criteria established by Duchenne. Chromatin negative Turner's syndrome is usually the consequence of a complete or partial (mosaic) XO sex-chromosome complement. The first report of DMD in a female was of a girl who also manifested Turner's syndrome $(45, \mathrm{XO})$, the condition presumably resulting from the presence of a defective locus on the single $\mathrm{X}$ chromosome.

Two-third of the mothers of affected boys are carriers and one-third are due to new mutations. About $10 \%$ of carriers have clinical symptoms referred as "manifesting carriers". Serum creatine kinase (CK) activity is raised in 45-70\% of the carriers and about $70 \%$ also have some histological abnormalities on muscle biopsy [6]. Measurement of serum CK was the most commonly used method for detecting at risk females.

Several disease-causing mechanisms have been implicated in DMD manifesting carriers. These include X-autosomal translocations disrupting the DMD gene,[7] mutations on both DMD alleles [8] and co occurrence of DMD mutations together with other genetic abnormalities such as X-chromosome monosomy [9], X-chromosome uniparental disomy [10] as well as male pseudohermaphroditism caused by a mutation in the androgen receptor gene [11]. However, the most frequently reported mechanism to provoke symptoms in DMD carriers is skewed X-inactivation, favoring the expression of the $\mathrm{X}$ chromosome with the DMD mutated allele [12]. Turner syndrome with an XO pattern is another rare situation which may coexist with DMD in a girl, since the abnormal $\mathrm{X}$ is not suppressed by the missing normal chromosome.

In our case the child had severe progressive muscular weakness with mental retardation manifesting in $1^{\text {st }}$ decade of life. The loss of genetic material from the $\mathrm{X}$ chromosome (XO karyotype) was responsible for the early and severe clinical manifestation of the disease in this phenotypic female. No affected males have been reported in the family of the girl, also the mother and father are healthy a finding consistent with the interpretation that the de novo translocation is responsible for the manifestation of the disease. The normal serum CK level in the mother suggests that mother is not a carrier. The presence of mental retardation is thought to be the result of the cumulative loss of Dystrophin isoforms in the central nervous system during development [13].

Molecular diagnosis from peripheral blood samples can detect $96 \%$ of mutations in patients with Duchenne muscular dystrophy by using these techniques in a 3-tiered approach. Tier 1 is PCR amplification to detect large deletions, tier 2 would use DOVAM (detection of virtually all mutations) to rapidly scan for point mutations, and tier 3 would use MAPH (multiplex amplifiable probe hybridization) to define duplications [14].

Carrier analysis in DMD is complicated due to the heterozygous nature of the $\mathrm{X}$ chromosome. Techniques used for carrier analysis in families where the mutation is identified includes quantitative multiplex PCR (qmPCR), Southern blot and multiplex ligation-dependent probe amplification (MLPA). Linkage analysis is used in cases without identifiable mutations [15].

In our case molecular diagnosis of index case and carrier analysis was not done due to unavailability of tests at our centre.

There is no cure for Duchenne muscular dystrophy. Treatment is generally aimed at controlling the onset of symptoms to maximize the quality of life. The treatments include: use of corticosteroids such as prednisolone and deflazacort, anabolic steroids like Oxandrolone to increase energy and strength, and defer severity of some symptoms [16]. ACE inhibitors and Angiotensin receptor blocking agents are used for myocardial preservation and improvement in left ventricular functions [17]. Physical therapy is helpful to maintain muscle strength, flexibility, and function. 
Future directions include gene therapy [18] to deliver DNA encoding dystrophin or other therapeutic genes, such as utrophin, to muscle.

Genetic counseling remains the sole intervention for preventing the disease. Initiate genetic counseling soon after the diagnosis has been made. Chorionic villus sampling and amniotic cell analysis permit prenatal diagnosis either by testing for a known deletion or duplication, or by linkage analysis [19].

\section{Conclusion}

Early diagnosis of dystrophinopathy in females requires a high index of suspicion. Dystrophinopathy should be considered in female of any age presenting with muscular and motor symptoms irrespective of family history. Molecular testing, genetic counseling and prenatal diagnosis should be emphasized to reduce the burden of disease in the community.

\section{References}

1. Gatta V, Scarciolla O, Gaspari AR, Palka C, De Angelis MV, Di Muzio A. Identification of deletions and duplications of the DMD gene in affected males and carrier females by multiple ligation probe amplification (MLPA). Hum Genet 2005; 117: 92-8.

2. Emery AE. Population frequencies of inherited neuromuscular diseases - a world survey. Neuromuscul Disord 1991; 1: 1929.

3. Muntoni F, Torelli S, Ferlini A. Dystrophin and mutations: one gene, several proteins, multiple phenotypes. Lancet Neurol 2003 Dec; 2(12):731-740.

4. Yoshioka M, Yorifuji T, Mituyoshi I. Skewed X inactivation in manifesting carriers of Duchenne muscular dystrophy. Clin Genet 1998 Feb; 53(2):102-107.

5. Hoffman EP and Kunkel IM. Dystrophin abnormalities in Duchenne and Becker muscular dystrophy. Neuron 1989; 2: 1019-29.

6. Bushby KM, Goodship JA, Nicholson LV, Johnson MA, Haggerty ID, Gardner Medwin D. Variability in clinical, genetic and protein abnormalities in manifesting carriers of Duchenne and Becker muscular dystrophy. Neuromuscul Disord 1993 Jan; 3(1):57-64.

7. Boyd Y, Buckle V, Holt S, Munro E, Hunter D, Craig I. Muscular dystrophy in girls with X;autosome translocations. J Med Genet 1986 Dec; 23(6):484-490.

8. Soltanzadeh P, Friez MJ, Dunn D, Von Niederhausern A, Gurvich OL, Swoboda KJ, Sampson JB, Pestronk A, Connolly AM, Florence JM, Finkel RS, Bonnemann CG, Medne L, Mendell JR, Mathews KD, Wong BL, Sussman MD, Zonana J, Kovak K, Gospe SM Jr, Gappmaier E, Taylor LE, Howard MT, Weiss RB, Flanigan KM. Clinical and genetic characterization of manifesting carriers of DMD mutations. Neuromuscul Disord 2010 Aug; 20(8):499-504.

9. Satre V, Monnier N, Devillard F, Amblard F, Lunardi J. Prenatal diagnosis of DMD in a female foetus affected by Turner syndrome. Prenat Diagn 2004 Nov; 24(11):913-917.

10. Quan F, Janas J, Toth-Fejel S, Johnson DB, Wolford JK, Popovich BW. Uniparental disomy of the entire X chromosome in a female with Duchenne muscular dystrophy. Am J Hum Genet 1997 Jan; 60(1):160-165.

11. Katayama Y, Tran VK, Hoan NT, Zhang Z, Goji K, Yagi M, Takeshima Y, Saiki K, Nhan NT, Matsuo M. Cooccurrence of mutations in both dystrophin- and androgen-receptor genes is a novel cause of female Duchenne muscular dystrophy. Hum Genet 2006 Jun; 119(5):516-519. 
12. Azofeifa J, Voit T, Hubner C, Cremer M. X-chromosome methylation in manifesting and healthy carriers of dystrophinopathies: concordance of activation ratios among first degree female relatives and skewed inactivation as cause of the affected phenotypes. Hum Genet 1995 Aug; 96(2):167-176.

13. Taylor PJ, Betts GA, Maroulis S, Gilissen C, Pedersen RL, Mowat DR, Johnston HM, Buckley MF. Dystrophin gene mutation location and the risk of cognitive impairment in Duchenne muscular dystrophy. PLoS One 2010 Jan 20; 5(1):8803.

14. Yan J, Feng J, Buzin CH. Three-tiered noninvasive diagnosis in $96 \%$ of patients with Duchenne muscular dystrophy (DMD). Hum Mutat Feb 2004; 23(2):203-4.

15. Panigrahi I, Mittal B. Carrier detection and prenatal diagnosis in Duchenne/Becker muscular dystrophy. Indian Pediatr 2001; 38: 631-9.

16. Corticosteroid treatment of Duchenne dystrophy: report of the Quality Standards Subcommittee of the American Academy of Neurology and the Practice Committee of the Child Neurology Society. Neurology Jan 11 2005; 64(1):13-20.

17. Duboc D, Meune C, Pierre B, Wahbi K, Eymard B, Toutain A. Perindopril preventive treatment on mortality in Duchenne muscular dystrophy: 10 years' follow-up. Am Heart J Sep 2007; 154(3):596-602.

18. Bowles DE, McPhee SW, Li C. Phase 1 gene therapy for Duchenne muscular dystrophy using a translational optimized AAV vector. Mol Ther Feb 2012; 20(2):443-55.

19. Clemens PR, Fenwick RG, Chamberlain JS. Carrier detection and prenatal diagnosis in Duchenne and Becker muscular dystrophy families using dinucleotide repeat polymorphisms. Am J Hum Genet Nov 1991; 49(5):951-60.

\section{How to cite this article?}

Nahrel R, Kosam A. Duchenne Muscular Dystrophy in a Female Child with Turner syndrome: A Case report. Int J Med Res Rev 2014;2(3):262- 266. doi:10.17511/ijmrr. 2014.i03.17 